\section{DATA \& \\ KNOWLEDGE ENGINEERING}

Editor-in-Chief:Peter Chen, Department of Computer Science, Louisiana State University, Baton Rouge, LA 70803-4020, USA,

Associate Editor: Reind van de Riet, Department of Mathematics and Computer Science, Free University, 1081 HV Amsterdam, The Netherlands,

Technical Area Advisory Editor for Data Engineering, Distributed Databases: Wesley Chu, Departement of Computer Science, University of California, Los Angeles, CA, 90024, USA

Technical Area Advisory Editor for Data Engineering, Database Design: Jane Liu, Departement of Computer Science, University of Illinois, 1304 Spring Ave.,Urbana, IL, 61801, USA

Technical Area Advisory Editor for Knowledge Engineering: Donald Walker, Bell Communications Research, 445 South Street, Morristown, NJ, 07960, USA

\section{AIMS AND SCOPE}

DKE covers the following topics: Representation and Manipulation of Data \& Knowledge Conceptual data models. Knowledge representation techniques.

Data/knowledge manipulation languages and techniques.

Architectures New architectures for

database/knowledgebase/expert systems. Design and

implementation techniques. Languages and user interfaces.

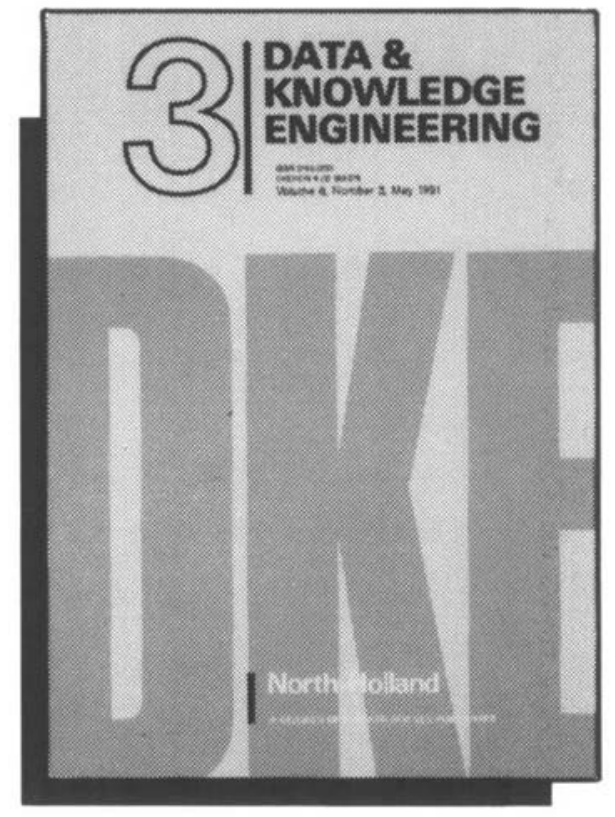

\section{Subscription Information:}

1992: Volumes 7-8 (8 issues)

Subscription price:

Dfl. 672.00 / US $\$ 333.00$

(including postage and handling) ISSN 0169-023X

The Dutch Guilder (Dfl.) price is definitive. US $\$$ price is subject to exchange rate fluctuations

\title{
Elsevier Science Publishers
}

\author{
Imprint North - Holland
}

\section{COUPON FOR A FREE INSPECTION COPY OF}

Send this form, or a photocopy to:

Elsevier Sclence Publishers

Imprint North - Holland

Attn: Petra van der Meer

P.O. Box 103

1000 AC Amsterdam, The Netherlands
DATA \& KNOWLEDGE ENGINEERING

For customers in the USA and Canada:

Elsevier Science Publishers

Attn: Journal Information Center

P.O. Box 882

Madison Square Station

New York, N.Y. 10159 U.S.A.

Name:

Professional Address: 


\section{The knowledge engineering review}

\section{Notes for Contributors}

Contributions for publication should be addressed to Dr John Fox, Editor, The Knowledge Engineering Review, Biomedical Computing Unit, PO Box 123, Lincoln's Inn Fields, London WC2A 3PX, England, Dr Peter Jackson, North American Editor, McDonnell-Douglas Research Lab, Artificial Intelligence Group, PO Box 5.16, St Louis, MO 63166, USA, or may be submitted through a member of the Editorial Advisory Board (addresses inside front cover). Submission implies that the manuscript has not been published previously nor currently submitted for publication elsewhere.

All contributions, whether articles, correspondence or reviews, must be sent in triplicate and typed on one side of the paper, with wide margins and double-line spacing throughout. Any minor corrections should be made neatly in the typescript, leaving the margins clear. The author is invited to nominate up to five possible referees, who will not necessarily be used.

Articles must be accompanied by a brief, informative rather than indicative, abstract. Headings should be set out clearly but not underlined. Primary headings should be in lower case, at margin, with arabic numeral; subheadings should be numbered 2.a., 2.b., etc., and tertiary headings, 2.a.1., 2.a.2. No cross-references should be given by page number, but 'above' and 'below' should be used with the section specified, e.g. Section 2.a.2. The SI system of units should be used. The author should mark in the margin of the manuscript where figures and tables may be inserted. References to points in larger works should, where possible, quote the page reference, e.g. Ager, 1981, p. 102.

Tables should be typed with double-line spacing on sheets separate from the running text. Each table must have a caption that will make the data in the table intelligible without reference to the text.

Illustrations should be drafted for reproduction as full page $(148 \mathrm{~mm})$ width. Originals should normally be drawn at twice final area and must be sent in a flat package; larger drawings may delay publication. Lettering should be of a size so that when reduced the smallest lower-case letters will not be less than about $1 \mathrm{~mm}$. Avoid gross disparities in lettering size on a drawing. Duplicates of illustrations should be sent, and may be prints or, preferably, photocopies reduced to final size. Illustrations in the text, both line drawings and photographs for halftone reproductions, will be referred to as figures (Fig. 2, 2a, etc.). Folding plates will not be accepted. Figures composed of photographs should be glossy prints presented at publication scale. Figure captions must be typed with double-line spacing on sheets separate from the running text.

The accuracy of references is the responsibility of authors. References must be double-spaced and spelt out in full, e.g.

Gale, W A, ed 1986. Artificial Intelligence and statistics, Reading, Massachusetts: Addison-Wesley

Pearl, J 1984. Heuristics. Intelligent search strategies for problem solving, Reading, Massachusetts: AddisonWesley

Tie-Cheng Wang and Bledsoe, W W, 1987. "Hierarchical deduction" Journal of Automated Reasoning 3 (1) ppl-34.

Pau, L F, 1986. "Survey of expert systems for fault detection, test generation and maintenance" Expert Systems, 3 (2) $\mathrm{pp} 100-111$.

Twenty Five offprints of each paper will be provided free of charge. Additional offprints may be purchased according to a set scale of charges if ordered when the proofs are returned. 


\section{The knowledge engineering review}

VOLUME 7 NUMBER 1 MARCH 1992

\section{Contents}

Qualitative reasoning over time: history and current prospects LOUISE TRAVÉ-MASSUYÈS

Qualitative frameworks for decision support: lessons from medicine JOHN FOX and PAUL KRAUSE

From knowledge bases to decision models

MICHAEL P. WELLMAN, JOHN S. BREESE and ROBERT P. GOLDMAN

The qualitative representation of physical systems

ENRICO COIERA

Book reviews

From the journals

\section{CAMBRIDGE UNIVERSITY PRESS}

Published by the Press Syndicate of the University of Cambridge

The Pitt Building, Trumpington Street, Cambridge CB2 1RP

40 West 20th Street, New York, NY 10011-4211, USA

10 Stamford Road, Oakleigh, Victoria 3166, Australia

\section{Typeset by Paston Press, Loddon}

Printed in Great Britain by Henry Ling Ltd, Dorchester 